\title{
CURRENT TRENDS IN RESEARCH ON BEHAVIORAL DEVELOPMENT IN THE FEDERAL REPUBLIC OF GERMANY *
}

\author{
Rainer K. SILBEREISEN and Petra SCHUHLER
}

Technical University Berlin, West Germany

Accepted April 1982

The state and perspective of developmental psychology in the Federal Republic of Germany is analyzed with respect to (a) professional education, (b) resources for research, (c) actual fields of research, and (d) media of professional communication. Current trends of research were investigated by a combination of multi-category content analyses of national (and international) journal publications, and survey data with respect to research interests and planned studies of German developmentalists. Included among the main trends are: (a) an increasing emphasis on longitudinal studies, sometimes combined with short-term interventions; (b) a growing interest in studies representative of natural conditions; (c) although still relatively rare, some of the studies employ a developmental perspective not only for persons but also for relations between persons and changes in environmental factors; (d) areas of heaviest concentration are cognitive development, social as well as personality development, with a trend towards more molar concepts of action-regulating systems instead of small-range models; (e) a growing number of studies on youth and adolescence; (f) new efforts towards a systematic elaboration of the application perspectives of developmental psychology. Professional education as well as research in developmental psychology was highly influenced by a 6-year program from the Volkswagen foundation. As a result, one could observe an increase in quantity as well as an improvement in quality both of teaching and research. Two further steps are now being planned: (a) a post-graduate program, the first one in German psychology, will start in 1983; (b) further efforts to broaden symmetric international communication and cooperation will be undertaken.

\section{Introduction}

In the years before 1933, German developmental psychology held a leading position in the international scientific community. Only a few

\footnotetext{
* Invited lecture to the Sixth Biennal Meeting of the International Society for the Study of Behavioural Development, 17-21 August 1981, Toronto, Canada. We thank Sabine Walper for her valuable assistance in literature processing and data collection.

Mailing address: R.K. Silbereisen, Technische Universität Berlin, Institut für Psychologie, Dovestrasse 1-5, D-1000 Berlin 10, West Germany.
} 
years of Nazi power were necessary to destroy German psychology in general, and above all developmental psychology. Many leading researchers emigrated.

After World War II, developmental psychology received a new impetus in the United States of America, in the Soviet Union, in Britain, as well as in France. Many new ideas emerged. To take but one example: the establishment of a life-span developmental psychology brought a new perspective on stability and change. Furthermore, developmental psychology in these countries was highly influential in the conception and evaluation of educational programs as well as in other fields of application.

Compared with the international situation in the beginning of the seventies, the state of developmental psychology in West Germany was desperate. Recently, in his review on 30 years of research on child psychology, Nickel described the sad condition of post-war child psychology (1980: 316): "It seemed natural to take as a point of departure the golden twenties of German child psychology and psychology of adolescence. This, however, resulted in rather fruitless controversies concerning unified and often idealized models of development which marked the first post-war decade. Child psychology was not able to extricate itself from the obsolete theoretical positions until the sixties, and to approach international research standards. The critique, however, was carried so far that the German research traditions were absolutely rejected. Consequently, the sixties were characterized by a lack of orientation which led to an almost uncritical adoption of North American developmental psychology".

Throughout this paper we shall confine ourselves primarily to the Federal Republic of Germany, including Berlin (West). That is, although the general trends in developmental research are presumably highly similar in Austria and the German-speaking section of Switzerland, this presentation will be limited to West Germany.

Developmental psychology in the German Democratic Republic had an orientation-seeking period too, but its subsequent development followed other tracks. Reviews by Kossakowski (1980) or Schmidt (1980) describe the general tendencies of East German psychology over the last 30 years. Kossakowski's article was published in the American Psychologist, whereas Schmidt's paper appeared in the Annual Review of Psychology.

In our short retrospect on developmental psychology in the Federal 
Republic of Germany, we shall now focus on the last decade. Early in the seventies, a group of psychologists convinced the Stiftung Volkswagenwerk (Volkswagen Foundation) that the desperate state of developmental psychology demanded a new beginning. In 1974, the foundation started a program which was aimed at supporting the establishment of a general infrastructure, as well as the accompanying funding of specific projects. This program covered several activities: exchange programs with foreign research groups, visiting professorships, over a dozen workshops with participants from abroad, as well as about 20 relatively large research projects.

Furthermore, in order to facilitate the initiation, coordination and dissemination of the various activities, an advisory board to the foundation was established (Rauh 1981). In total, about nine million Deutschmarks (3.6 million US-dollars according to the exchange rate at that time) were spent on these efforts to develop developmental psychology. The program was terminated after six years in 1980. The bulk of the funded empirical work is still in progress, however. Although an ultimate evaluation has to be postponed, preliminary estimates of this exemplary priority program were in general extremely positive (Weinert 1980).

Current trends in developmental psychology in West Germany are highly influenced by the Volkswagen program. Finally, one of the sponsored events, the International Seminar for Developmental Research held in 1977, should be mentioned separately. During this conference an intensive dialogue between German and American developmentalists took place for the first time in the post-war years. These contacts, documented in a comprehensive book edited by Montada (1979), led to insights which obviously surprised both parties: many of the seemingly brand-new ideas were not only rooted in German research traditions, but had been systematically elaborated over the years - unfortunately, totally unnoticed by English-speaking psychologists. Nickel (1980), perhaps slightly exaggerated, described this seminar as the beginning of a new self-esteem among German developmentalists. Moreover, the question of international communication, and particularly the problem of overcoming the one-sidedness of the exchange between North American - as well as colleagues from other countries and German developmental psychologists, have been permanently discussed since then.

An informed expert of German post-war developmental psychology 
may wonder why the important work of Thomae's group at the Univerity of Bonn has not lead earlier to a nation-wide emphasis on developmental psychology. As early as in the beginning sixties they established the contours of a perspective which is now familiar to us as the life-span perspective. Important contributions from that period are Coerper et al. (1954), Lehr (1969) and Thomae and Lehr (1965).

The Stiftung Volkswagenwerk funded the Bonn Longitudinal Study of Aging (see Thomae 1976) since 1965 (in 1980/81 the seventh wave was collected, again funded by the foundation). Unfortunately, these early efforts did not influence the position of developmental psychology at other departments too much. Perhaps the reception by students and schools of psychology was hindered by the specialization of the Bonn group on problems of gerontology. The Zeitgeist could have been another reason: at that time, narrative interview techniques and subjective conceptions of life-events - a main issue of these early studies were not the accepted state of the art. Seen from today's perspective, somehow paradoxically, the former Bonn studies are absolutely in line with recent trends.

We conclude with a brief comment on the organization of the materials we are going to present. Reviews on the state of a field of science seem to belong to one or the other of two prototypes: either the author concentrates on research only, or she/he describes research efforts as a part of a larger scientific infrastructure. An infrastructure which consists (1) of the conditions of professional education of future researchers, (2) the manpower and equipment of psychology departments and research facilities, (3) the resources for research, and - last but not least - (4) the network of professional communication.

The following presentation of the state and trends of developmental psychology in the Federal Republic of Germany is modeled after the latter prototype. It is organized around the general outline of Irle's (1977) article on "The State of Psychology in the Federal Republic of Germany", and complements Nickel's (1980) already mentioned review on "Child Psychology: Thirty Years of Research in the Federal Republic of Germany". - Both papers were published in English in the German Journal of Psychology, a journal which is especially devoted to providing up-to-date information on the progress and current state of psychological science in German-speaking countries.

In section 2, we would like to present some information on the conditions of professional education in developmental psychology. 


\section{Professional education in developmental psychology}

On the average, $2 \frac{1}{2}$ years are required to finish undergraduate studies in West Germany. The student takes courses in seven fields, one of them involving developmental psychology. Frielingsdorf and Rauh (1977) gathered data on the numbers of courses in developmental psychology. According to their results, only 3 courses per year were given on the average. Certainly, this disadvantaged position of developmental psychology is better today as a side-effect of the already mentioned priority program for developmental psychology.

Graduate studies formally require a minimum of 2 to $2 \frac{1}{2}$ years of study. A graduate student has to decide on her/his preferences within three sections of studies: theoretical psychology, methodology of psychology, and fields of applied psychology. Generally, each department offers a different selection in each of these three sections. Graduate students ask for clinical psychology as a field of applied psychology in nearly all departments (Irle 1977; Eyferth 1980). Only in a few departments, for instance Bochum, Bonn and Heidelberg (Frielingsdorf and Rauh 1977) are graduate studies in developmental psychology offered [1].

A diploma thesis (Diplomarbeit), mostly based on an empirical investigation, forms part of the student's final examination (Diplom). If well organized, investigations conducted by graduate students support the research efforts in the departments. Therefore, the lack of graduate programs in developmental psychology has a crucial effect on development research, too. In 1975 (Frielingsdorf and Rauh 1977), only about $6 \%$ of the diploma theses dealt with studies within the scope of developmental psychology; the comparable figure for dissertations was about $8 \%$. One of the positive results of the Volkswagen program was a remarkable doubling: from a content analysis of relevant information in the 1981 issue of the Psychologische Rundschau, we calculated 12\% $(n=782)$ for diploma theses, and $18 \%$ for dissertations $(N=45)$. These data portray theses and dissertations completed around 1980 - only 5 years after the survey of Frielingsdorf and Rauh.

There are almost no institutionalized postgraduate studies leading to the completion of a doctoral thesis. This is another serious restriction

[1] The most recent data regarding courses in developmental psychology show (Ewert pers. comm.) that on the average 4 courses were given per term. 
on the professional training of future researchers. A group of researchers from Berlin and Trier (Baltes et al. 1981), is now preparing for a postgraduate program in developmental psychology, however. Again supported by the Volkswagen foundation, the program including annual summer schools and project seminars will be started in 1983.

Unfortunately, there is another reason for students to increase their overemphasis on clinical training: in 1980, 1.000 psychologists were unemployed, twice as many as in 1975. Also in 1980, there were five unemployed psychologists for each vacancy (Roth 1981). Taking on clients for therapy, however, seemingly allows many of them to bridge a period of unemployment.

In section 3 some information will be given on resources, that is manpower and equipment, and - above all - institutions supporting research on developmental psychology.

\section{Resources for research}

In 1981 there were 33 psychology departments in the Federal Republic of Germany. Nearly 900 individuals work in teaching positions from assistant (assistant professor) to (full) professor. The number of students is about 16.000. These figures (estimated from the Psychologenkalender, Hogrefe 1981) already exceed the 1977 data of Irle.

With regard to developmental psychology, Frielingsdorf and Rauh (1977) reported only 58 teaching positions (total in that year about 700) unequally distributed over 26 departments. In 1981, presumably as a side-effect of the Volkswagen program, developmental psychology was represented by a professor and her/his crew of assistants in nearly every department (Weinert pers. comm.).

In general, sufficient equipment and facilities of chairs for developmental psychology is the exeption, not the rule in West Germany (Frielingsdorf and Rauh 1977).

Several institutions support research on developmental psychology. As already mentioned, the Volkswagen foundation started its priority program in 1974. The processing of further proposals was terminated in 1980. During the last period of funding, two focal points were set: (1) development of information processing, and (2) development of action control (see Zeitschrift für Entwicklungspsychologie und Pädagogische 
Psychologie, 1979, 11, 181-184; abbreviated: ZEP).

The Deutsche Forschungsgemeinschaft (DFG, German Research Council) gives several types of grants (see DFG 1979: 37-54; Irle 1977). Priority programs (Forschungsschwerpunkte) are especially suited for investigating new research problems. In 1979, the DFG started several priority programs which are also relevant for developmental psychology: Verbal Interaction, Educational Research on Adolescence, Social Attitudes and Behavior, and Psychological Ecology. The program for research on adolescence, for instance, comprises a six-year longitudinal study on personality development and participation in youth cultures (Silbereisen and Eyferth 1981).

The highest level of organization and financial input is reached in the Sonderforschungsbereiche (SFB). Of the more than 100 SFB, only a few have some importance for developmental research: for instance, Research on Socialization and Communication located in Erlangen, Research on Development and Education at the University of Konstanz, and Social Psychology Research on Decision-Making Processes, a SFB located in Mannheim [2].

Comparable to the SFB are the research institutes of the Max Planck Gesellschaft, which operates independent of universities. At three institutes developmental psychology is a focal point of research: in Nijmegen (The Netherlands), psycholinguistic research is concentrated; at the Max Planck Institute for Human Development and Education in Berlin, Baltes is now organizing a new research group; and in Munich, Weinert heads a group at the Max Planck Institute for Psychological Research.

The conditions for developmental research would be incompletely described without referring to the more subjective factors. Fisch and Daniel (1981) shed some light on the consequences of a governmental policy which led to neglecting research at the universities in favor of teaching (see Irle 1979). According to their report on a national survey of university teachers, psychologists describe the state of research at their departments as absolutely hopeless. No other discipline is evaluated as negatively as psychology. Psychologists feel themselves exploited by teaching and administration.

If one tries to identify the causes behind these attitudes, according to Fisch and Daniel (1981) the strongest single factor is the lack of

[2] The speakers of these SFB's are Ronneberger, Peisert, and Kieser, respectively. 
qualified research personal. This, however, seemingly belongs to a vicious circle - especially for developmental psychology: the poor qualifications of young researchers who are typically hired for research is an ultimate result of the deficient graduate studies, as well as the previous lack of post-graduate programs.

After having established a framework by informing about the deficiencies in professional education and the scope of resources for research, we will concentrate on recent trends in research.

\section{Actual fields of research}

With regard to trends in developmental psychology in West Germany several sources are available: (1) In a survey Frielingsdorf and Rauh (1977) gathered data on research activities. Their results, however, represent the answers of researchers as to how they define research at their departments, not what is published. A report of Waller (1974) on trends in developmental psychology is likewise restricted to the state before the priority funding of developmental psychology was initiated. (2) Two publication analyses appeared in the last years. Groffmann (1978) analyzed 26 journals in the German language as to how often research on developmental psychology could be said to be related to theories of development. Unfortunately, his data are confined to articles from 1944 to 1973 . Therefore, they do not represent the new efforts which were started in 1974. Nickel (1980) examined 24 journals printed in German in his search for contributions relevant to child psychology. His analysis of articles from 1947 to 1978 , however, is mainly restricted to the content-areas of the studies. (3) The reports on the meetings of developmentalists since 1976 (Heckhausen 1976; Waller 1977; Keller 1978; Silbereisen 1980b; Oerter 1982) include comprehensive lists of the topics of the study groups.

To provide an actual base for the present report, the information from these sources will be complemented by specially conducted analyses of recent publications, as well as by survey data on planned research and researchers' interests in certain fields of study. A more valid and comprehensive insight into recent research activities will hopefully result from this combination.

We shall describe the method of the analyses very briefly: (1) All developmental studies published in the abstract section of the German Journal of Psychology (GJP) from 1977 (the first issue) to 1981 (cut off 
date July 1, 1981) were analyzed. This journal covers the content of a total of 44 current German language journals.

(2) The analysis of research interests was prepared by a short questionnaire distributed to all scientists included in a directory of individuals active (or at least interested) in developmental research (Adressenverzeichnis Entwicklungspsychologie, see section 5). Respondents were asked to judge their research interests according to a comprehensive category system, as well as to describe their planned or ongoing research in terms of subjects, method and content. The actual purpose of the questionnaire was to prepare for a new edition of the directory.

(3) To facilitate comparisons with trends in developmental psychology abroad, articles published in Child Development from 1978 to 1981 (cut-off date July 1, 1981) were also included in the analysis.

(4) Schmitz (1979) analyzed abstracts of developmental research published in the Psychological Abstracts. His results on the year 1975, as well as McCandless and Geis' (1975) data on manuscripts submitted to Developmental Psychology, is useful for occasional comparisons.

In table 1, the total number of studies, as well as the number of studies included in the analyses, are summarized. In the period from 1977 to 1981, a total of 94 studies was abstracted in the GJP. If one excludes chapters, books and publications from the German Democratic Republic, only 65 journal articles on developmental psychology remain. Calculated on a per-year base, the number of all German journal articles amounts to about $10 \%$ of the articles published in Child Development per year in a comparable time-period. A total of 200 researchers responded to the questionnaire (that comprises about $80 \%$ of the questionnaires mailed out). They reported 205 current studies; 30

Table 1

Numbers of research items.

\begin{tabular}{lcc}
\hline Source & Total & Included \\
\hline (1) German Journal of Psychology 1977-81 & 94 & $65^{\text {a }}$ \\
(2) Current studies & 205 & $175^{\mathrm{b}}$ \\
(3) Child Development 1978-81 & 594 & 594
\end{tabular}

\footnotetext{
a Chapters, books, and publications of authors from the German Democratic Republic excluded.

b Non-developmental studies excluded.
} 
of this group were excluded as being non-developmental. The ratio of 65 journal articles in a four-year period to 175 current studies seemingly indicates an increase in activities. This ratio, however, should be taken with caution: some of the current studies will probably be terminated without published results. In addition, the respondents marked a total of about 300 research interests as to type of subjects, and as to area of content.

The studies from the three sources (abstracts in GJP, current studies, and Child Development) were analyzed as to (1) type of subjects studied, (2) design conducted, (3) content area investigated, (4) setting considered, (5) method employed, and (6) theory applied. Due to the small number of German articles published, only gross differences between the sources under consideration should be interpreted.

In the following subsection, comments will be given on subjects and designs.

\subsection{Subjects and designs}

The types of subjects studied by developmental psychologists are summarized in table 2.

Data with regard to the German scientific community (journal abstracts, current studies, and research interests) were compared with articles in Developmental Psychology and Child Development.

In general, all sources from both cultures show a substantial imbalance of age groups studied. This imbalance is, strictly speaking, incompatible with a life-span perspective. The areas of heaviest concentration have clearly been the pre-school and school years (lines 2 and 3).

Corresponding with their editorial policy, Child Development demonstrates a greater emphasis on infancy and the preschool years, whereas Developmental Psychology shows more of an orientation towards a life-span perspective. If one compares the profile of the recent German journal publications with the common trend in the rates of age groups in the American journals, only two distinct differences appear: (1) The percentage of studies working with children in their elementary school years is apparently lower (line 3). (2) Research on the aged, nearly overlooked even in Developmental Psychology, received a remarkable interest by German researchers (line 6). The rate of research on adult and aged taken together resemble the international state (about $14 \%$ in 1975; Schmitz 1979). A review of research on psychogerontology in 


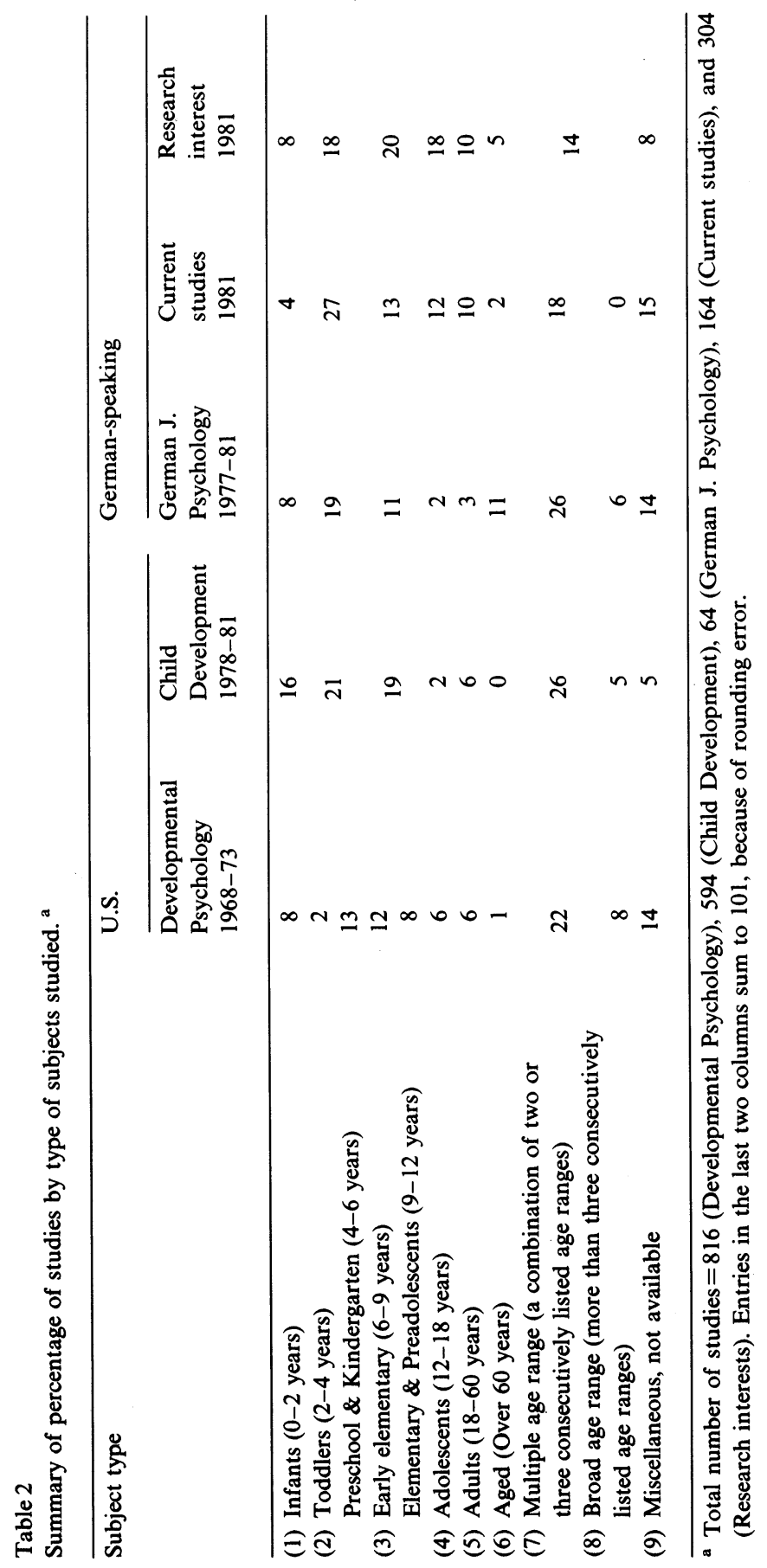


Germany was recently published in English by Thomae (1978).

Within the German sources, as summarized in table 2, there are two eminent differences between published research on the one hand, and current studies as well as research interests on the other hand: (1) Whereas journal publications abstracted between 1977 and 1981 did not deal with development in adolescence, several current studies and even more research interests concentrate on this age group (line 4). With very few exceptions (see Oerter 1979) developmental research on adolescence awaits a new beginning in Germany. Of course, there are numerous studies related to education and socialization. For instance, among the 107 empirical studies published from 1978 to 1981 in the Zeitschrift für Entwicklungspsychologie und Pädagogische Psychologie (educational psychology in German-speaking countries comprises noninstitutionalized socialization as well), $16 \%$ deals with adolescent subjects. Studies on youth development, however, which utilize theories and methods of developmental psychology are very rare. The increasing interest in developmental processes of adolescence represent a clear trend of developmental psychology in the Federal Republic of Germany. (2) The second main difference between published research and current studies or research interests involves the investigation of multiple or broad age ranges.

In all journal sources (North American as well as German), about $\frac{1}{3}$ of the studies use multiple age samples (lines 7 and 8). Studying multiple age groups, however, is not equivalent to longitudinal research, and vice versa. In table 3 a break-down of studies according to the type of design conducted is summarized.

As the first column of the table indicates, only $4 \%$ of the studies which were abstracted in the 1975 issue of Psychological Abstracts used repeated measurement (longitudinal or sequential). On the other hand, $46 \%$ of the designs conducted follow a cross-section strategy, and the other half $(49 \%)$ worked with groups of one age only.

In general, the published research in Child Development as well as $G J P$ follows similar tracks. A distinct difference, however, is demonstrated between published research and current studies which are presently incompleted: over $30 \%$ of these studies use (or intend to use if a study was started recently) longitudinal designs. If one checks table 2 against table 3 , a seeming paradox attracts attention. The relation between journal publications and current studies with respect to multiple age groups and repeated measurement designs is reversed. This, 


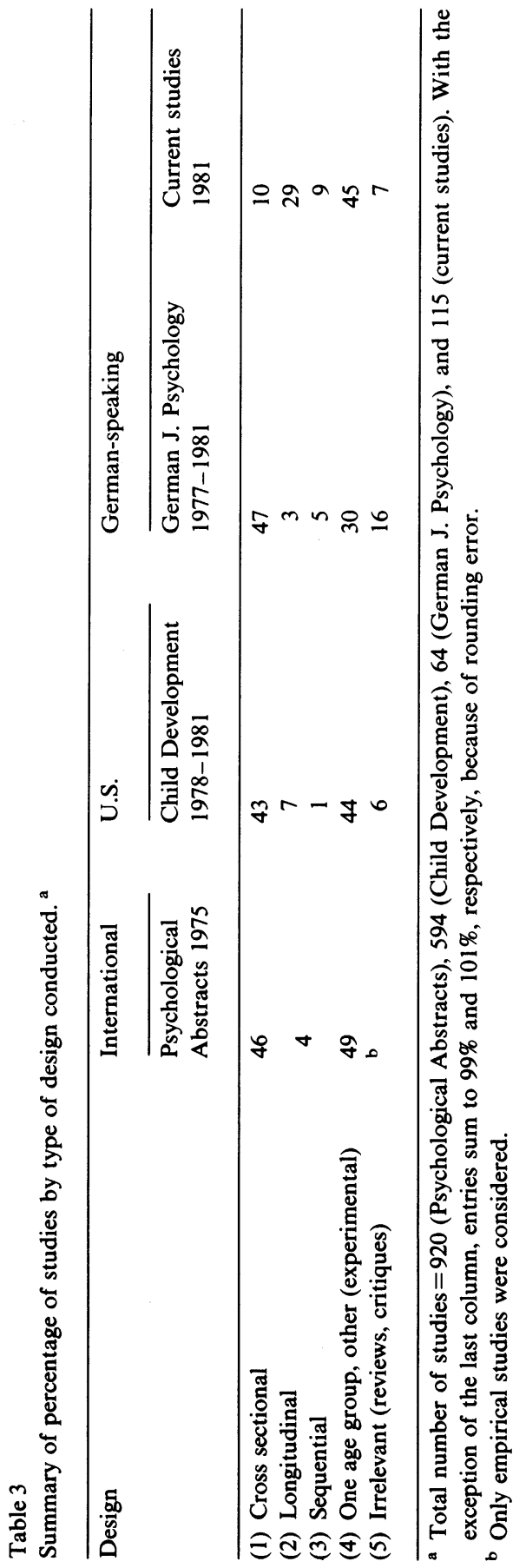


however, can be explained by differences in the placement of longitudinal studies across the life-span. Unlike research traditions represented in the journals, the current longitudinal studies of West German researchers usually do not include adjacent periods of the life-span. In several studies the time period covers a few months or even only days. This is especially true for studies on early experiences (Keller 1979). Short-term longitudinal studies on critical life events and the subsequent processes of coping (Vetter 1980) are another example.

The increasing emphasis an longitudinal studies will become one of the prominent trends of developmental psychology in the Federal Republic of Germany. Presumably, the younger generation of developmentalists has been highly influenced by Thomae's (1979) request for more longitudinal research in the context of the life-span.

We should like to go into some more details. At the 1979 meetings of developmentalists, Merz and Ehlers (1980) brought together twelve research groups dealing with longitudinal research. Three kinds of studies could be distinguished: (1) Follow-ups with parents and children of the longitudinal study on pregnancy and child development (Deutsche Forschungsgemeinschaft 1977). The children were seen (1979) in their early elementary years. (2) Longitudinal studies on school and university socialization. The Augsburg study (Hanke et al. 1980) on stability and change during the elementary school years is a more prominent one, encompassed were all children living in the city of Augsburg starting school in 1967. Another example is the work on teacher attitudes of a research unit (see Dann et al. 1978) at the University of Konstanz: over a period of eight years, Hohner and Dann (1979) analyzed the relationship between conservatism and ecological as well as career factors. (3) Representative for the third group of studies is the Bonn Longitudinal Study of Aging (see Thomae 1976, for a short presentation in English) which started as early as 1965.

Among the current studies summarized in table 3, there are many investigations seemingly unknown to Merz and Ehlers two years ago. Several examples should be quoted: (1) Voss (1979) is working on exploratory behavior and curiosity development of toddlers. Rauh et al. (1979) investigate the equilibration of cognitive structures over a one year period. In this project, for instance, a longitudinal design is systematically combined with short-term interventions. Especially interesting seems to be a study of Kreppner et al. (1978; see also Kreppner 1978). They describe the change of communicative patterns within 
families after the birth of the second child. (2) Over a two year period several studies on adults and aged were reported recently. Among them are studies on life-events and self-concept development (Mummendey and Sturm 1981), future time perspectives (Burger et al. 1981), personality development of young skilled workers (see Hoff 1981), a four-year study of five cohorts of adults aged 35 to 75 years (Filipp et al. 1980) and a micro-analytic approach to environmental factors and processes in psychological aging (Baltes and Baltes 1982). (3) There are also studies on multiple, adjacent age groups, as defined in lines seven and eight of table 2. Edelstein et al. (1976) investigate the relationship between social cognitions, action competences and socioecological structures. Their sample of children from Iceland is observed several times from 7 to (planned) 15 years of age. Trautner (1981) started a study on sex role development from three to ten years of age. (4) Apart from work on school socialization, longitudinal studies on adolescents (as well as in general) are very rare. Two of the few exceptions are Eckensberger (1981) on moral development, and Silbereisen and Eyferth (1981) on the relation between coping strategies, participation in youth cultures, and substance use. In the latter study, a representative sample of over 2.000 adolescents from the City of Berlin are followed from the age of 11 to 17 .

To sum up, longitudinal research seems to have a boom in the next years in West Germany. There are, however, several problems to be solved which await new ideas: (1) The bulk of the studies mentioned is granted (by the German Research Council, the Volkswagen Foundation or the Max Planck Gesellschaft). Nevertheless, there is a severe lack of coordination and cooperation between the various research groups. Hopefully, developmentalists (perhaps supported by the Deutsche Gesellschaft für Psychologie or ZUMA, a central research facility of the German Research Council) will initiate activities for solving this problem. (2) Another case in point which was already mentioned by Merz and Ehlers (1980), is the consideration of ecological and environmental factors. Many of the studies deal with this problem in a rather insufficient way. More investigations into change patterns of mutual person by situation influences are urgently needed. This is a case where sociologists, researchers of the priority program on ecological psychology (funded by the German Research Council (see section 1) as well as statisticians should cooperate. One of the important questions, for instance, concerns the construction of causal models which allow the 
integration of individual as well as group and ecology data (Rudinger 1981; Silbereisen et al. 1981).

\subsection{Settings and methods}

In the various content analyses of journal publications (for instance Schmitz 1979; Groffmann 1978), no attempts were made to differentiate the studies with regard to the intended representativeness for a certain setting or ecology.

In table 4 data are summarized which shed some light on the consideration of ecological perspectives in developmental psychology.

Studies in Child Development, those abstracted in the GJP as well as the current studies of German researchers were compared with regard to (1) nine types of settings (lines 1 to 7); (2) a category comprised of studies aimed at a multi-variate analysis of change patterns, primarily confined, however, to person variables; (3) finally, a category which

Summary of percentage of studies by settings. ${ }^{\text {a }}$

\begin{tabular}{|c|c|c|c|c|}
\hline & \multirow{3}{*}{$\begin{array}{l}\text { U.S. } \\
\text { Child } \\
\text { Development } \\
1978-81\end{array}$} & \multicolumn{3}{|c|}{ German-speaking } \\
\hline & & \multirow{2}{*}{$\begin{array}{l}\text { German } \\
\text { J. Psychology } \\
1977-81\end{array}$} & \multicolumn{2}{|c|}{$\begin{array}{l}\text { Current studies } \\
1981\end{array}$} \\
\hline & & & Total & $\begin{array}{l}\text { Basic } \\
\text { only }\end{array}$ \\
\hline (1) Biological factors & 1 & 1 & 3 & 3 \\
\hline (2) Early experiences & 8 & 1 & 6 & 6 \\
\hline (3) Family & 7 & 11 & 6 & 8 \\
\hline (4) Extrafamilial institutions & 1 & 5 & 5 & 4 \\
\hline (5) Schools & 0 & 2 & 3 & 0 \\
\hline (6) Sociocultural influences & 5 & 2 & 12 & 13 \\
\hline (7) Other settings & 9 & 0 & 18 & 7 \\
\hline \multicolumn{5}{|l|}{ (8) Change patterns (mostly } \\
\hline person variables) & 17 & 22 & 23 & 27 \\
\hline (9) Laboratory, external & & & & \\
\hline validity questionable & 51 & 56 & 24 & 33 \\
\hline \multicolumn{5}{|l|}{ (10) Total settings (= rows } \\
\hline 1 to 7$)$ & 31 & 22 & 53 & 41 \\
\hline
\end{tabular}


included laboratory studies with practically no attempts at ecological validity.

As the rates in table 4 demonstrate, there are only slight differences between the German-language research literature and Child Development. According to our calculations, about $\frac{1}{3}$ of the articles in Child Development claim ecological validity. The rate of settings in German articles is even lower and amounts to about $20 \%$ (see line 10). These figures correspond quite well to data reported by Bronfenbrenner (1977): in the early seventies, about $24 \%$ of the studies published in relevant U.S. journals were conducted in laboratory settings.

If one looks at the column representing current studies, however, there are remarkable deviations from the profile of published studies. Here the total amount of studies dealing with settings is about 50\% (line 10). The rates in three categories are especially responsible for the mentioned difference. The percentage of laboratory studies is much lower (line 9), sociocultural differences as well as several other settings (lines 6 and 7) received more attention.

In the last column, the subgroup of studies explicitly aimed at basic research is summarized. Obviously, the greater attraction of ecologically valid studies is not confined to applied developmental research. The increasing emphasis on studies representative of natural conditions seems to be a general trend.

In the following, some examples will be quoted.

(1) Biological factors, early experiences, family. According to Nickel (1980), particular attention has been paid to mother-child interaction and maternal deprivation. The biological determinants of childhood development have been analyzed in detail on the one hand, as well as different conditions of family socialization, on the other (Papousek and Papousek 1978; Grossmann, 1980; Keller and Werner-Bonus 1978). A comprehensive book containing numerous studies on family socialization was edited by Lukesch et al. (1980). Besides basic research, intervention in the family system was considered.

(2) Extrafamilial institutions, schools. Research on extrafamilial institutions was concentrated on the preschool years, for instance the effects of institutional upbringing on childhood development (Beller 1979). Nickel and Schmidt-Denter (1980) published their results of comprehensive studies on social development in Kindergartens. With regard to 
school settings, the review of Weinert et al. (1979) on educational psychology is highly informative.

(3) Sociocultural influences, other settings. With regard to sociocultural influences, the earlier studies were mostly confined to the investigation of various indices of SES. As is well known, however, these indices do not fit the language of psychology. Among the numerous current studies, there are attempts which approach influences from the sociocultural domain in a quite different way. A prominent example is the work of Oerter, for instance published in Oerter et al. (1977): they constructed a model of cognitive socialization which postulates isomorphism between the environmental structure and individual structure. From their model, they draw specific assumptions about problem-solving behavior in daily life situations. Other researchers refer to life-space conceptions (Becker 1981).

The lion's share of current studies which were included in the other-settings lable is related to environmental factors in occupational socialization and personality development. Important examples are the studies of Volpert and his colleagues (Volpert 1982, for an English-language presentation), and the work of a study group at the Max Planck Institute for Human Development and Education (see Hoff 1981).

Let us add one crucial point: the increasing emphasis on ecological settings does not automatically imply that the researchers' perspectives are orientated towards developmental aspects of the setting. For instance, the impact of the family system could be investigated without looking at the changing pattern of the family itself (as a consequence of other influences). The bulk of the studies mentioned in the last paragraphs, indeed, do mainly concentrate on the stability and change of the person variables. One of the few exceptions, for instance, is the already mentioned study of Kreppner et al. (1978) on developmental patterns of the entire family system.

These remarks may be sufficient for a brief summary. A stronger orientation towards ecological validity has been one of the demands on developmental psychology in Germany. On the other hand, this could be incompatible with another demand, i.e. the causal analysis of determinants of development.

With regard to this problem, table 5 gives some information. The ratio of experimental to correlative studies (lines 1 and 2) is somewhat 
Table 5

Summary of percentage of studies by techniques of research. ${ }^{\text {a }}$

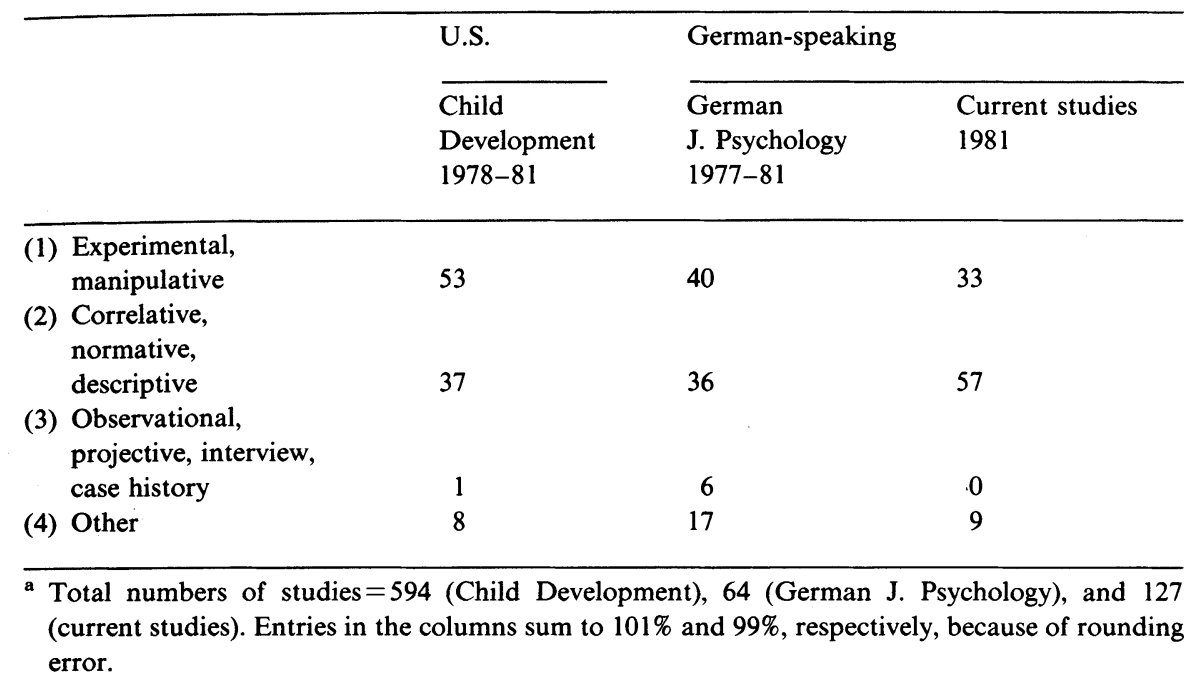

more homogeneous in the German research literature. About $40 \%$ of the studies employ one or the other of these methods. Researchers of current studies, however, seemingly prefer studies which employ correlative-normative-descriptive strategies.

A combination of experimental as well as non-manipulative strategies, of course, would best fit the requirements of developmental-ecological research. Unfortunately, complex approaches of this sort as well as non-obtrusive experimental methods have rarely been employed. Generally speaking, the renewed emphasis on qualitative interpretative approaches seems to be a general trend in West German social sciences. Especially susceptible to these methods (for instance, narrative interviews) seems to be research on life-events, youth culture (see Siegert 1981) as well as many studies conducted in a Kohlbergian tradition (for instance Döbert and Nunner-Winkler 1975).

\subsection{Content-areas and theories}

The content-area classification of studies compared between the international, the North American, as well as the German scientific community is summarized in table 6 .

By and large, the two U.S. periodicals' profile as well as that of GJP 


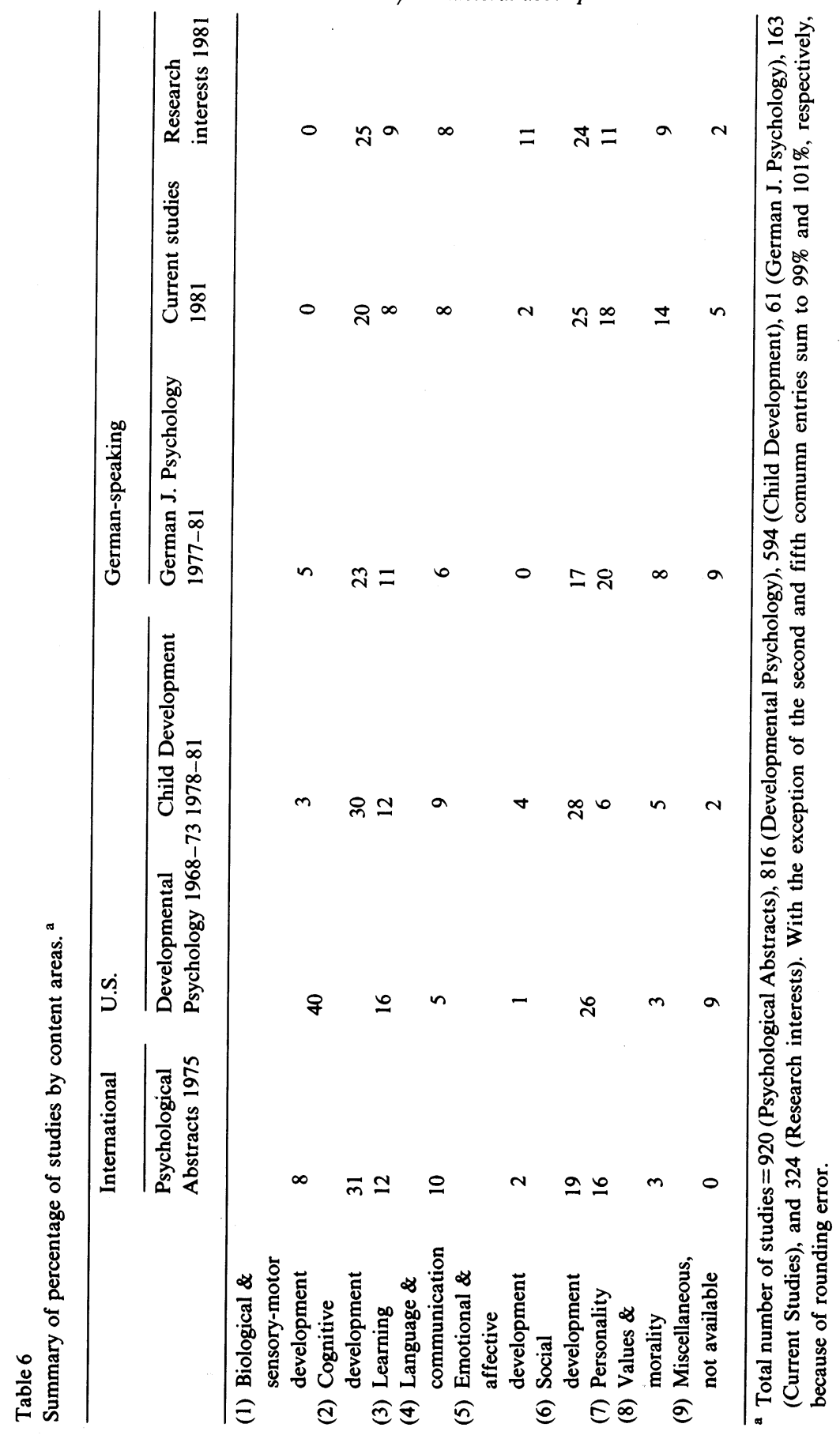


coincides with the profile of international publications (abstracted in the 1975 issue of Psychological Abstracts). Areas of heaviest concentration are cognitive development, social development as well as personality development. There are no striking differences between current studies and those already published.

The rates of content-areas depicted in table 6 are confirmed by Nickel's (1980) content analysis of German-language journal contributions over the last 30 years. Since the sixties, as a matter of fact, the most frequent and most rapidly increasing topics were cognitive development and personality as well as social development. Another check on the representativeness of the general outline given in table 6 is provided by a comparison with the topics of study groups discussed at the meetings of developmentalists. At the 1979 meeting in Berlin (Silbereisen 1980a), for instance, 9 out of 13 study groups dealt with cognitive or social development.

Comments on several of the content-areas follow successively. As is the case throughout this paper, examples of studies and publications have to be restricted to major sources.

(1) Sensory-motor development. According to Nickel (1980), sensorymotor development has never made up more than a $1 \%$ rate of all publications printed in German over the last 30 years. As table 6, row 1 demonstrates, there is no chance to overcome this neglect in the near future (in row 1, sensory-motor and biological development is confounded: the percentage of articles, current studies as well as research interests is very low).

(2) Cognitive development and learning. A breakdown of the broad content-areas regarding cognitive development and learning showed three subcategories with especially high rates: (1) perceptual processes, (2) problem solving and information processing, and (3) memory.

The percentage of studies on perceptual processes is remarkable: $12 \%$ in $G J P, 4 \%$ of current studies and research interests. In the last few years, studies concentrated (Nickel 1980) on the stimulation of perceptual development, and on the investigation of relationships between perceptual and concept development. Examples include Fischer (1979), Ritter and Rotarius (1978), and Gerber and Fischer (1981).

The clearest difference between Child Development and the German literature published in journals regards the development of problem 
solving and information processing. Only $1 \%$ of the German articles belong to this category, compared with $13 \%$ in Child Development. This disparity, however, is a function of the time-lag between conducting and publishing a study. There are several important studies in progress: Wilkening (1979, 1981; see also Wilkening et al. 1980) on information integration, Kluwe (1981) on the development of cognitive knowledge and excecutive control, and Spada's work on the development of thought processes (Hussy 1979; Kluwe and Spada 1980; Spada 1978; Foppa and Groner 1981). Scientists working on the development of information processing regularly publish their results in U.S. or international journals printed in the English language. Up to now, however, this communication strategy has rarely been employed by German developmentalists. We will return to the problems of professional communication in section 5 .

A comparatively expanding field is memory development (Wimmer 1976).

(3) Emotional and affective development. If one looks at table 6 again, a surprising constellation of the rates of published papers, current studies, and research interests attracts attention: there are no research efforts at all, on the one hand, but a relatively high $(11 \%$, line 5) rate of research interests. Apparently, the generally growing interest in the psychology of emotion has not yet reached the research labs of German developmentalists. This topic, of course, will become a very dynamic field in the next years. So far, experimental and social psychologists (for instance, Scherer 1981) as well as personality researchers (Lantermann $1980 \mathrm{~b}$ ) dominate the field.

If one systematically tabulates research interests in emotional development with all other content areas (details are omitted here), an interesting relationship appears: there are two distinguishable patterns of interest in emotional development, one of which shows a strong relation to the study of social development, whereas the other is related to cognitive development. The latter pattern receives an increasing amount of attention in West Germany. It is this relation which was neglected over the years by the popularity of "rational" views of human nature (see Mandl and Huber in press).

(4) Social development. According to the study groups held at the meetings of developmentalists (Rauh 1981), three central points of 
interest could be distinguished: (1) Socio-emotional development in early childhood (see Grossmann 1980 for a review), (2) social behavior, particularly the development of social relationships (Nickel and Schmidt-Denter 1980), and (3) social cognition (see Eckensberger and Silbereisen 1980 for a representative collection of recent studies; Chapman in press, for a review).

The state of this field seems to be characterized by (1) a lack of studies on social behavior in recent years (Schmitz-Scherzer 1977). (2) Up to now, research on social cognition has been unrelated to studies on social behavior. Only recently, attempts were made to deal with both topics in an integrated framework of action psychology (v. Cranach et al. 1980).

(5) Personality. Research on variables such as curiosity, self-concepts, coping processes, development of motive systems, and the like were subsumed under this heading.

Regarding curiosity and exploratory behavior, much work has been done by Voss (1979; Voss and Keller 1981). Apparently, more research efforts will be made in the future [3]. During the last few years, a stable group of researchers has been interested in the development of self-concepts (see Filipp 1980 for an overview). Research on the development of coping processes will become an important topic in research (Olbrich et al. 1980; Silbereisen and Eyferth 1981; Krohne 1980).

A tendency toward the application of highly complex models and approaches can be observed in the study of motivational systems. Perhaps the best example is a longitudinal study of Heckhausen on the development of patterns of action organization. In this study, the relation between the numerous constructs included in models of achievement motivation and behavior will be analyzed. Change within (synchronic analysis) as well as between (diachronic analysis) the domains of the constructs will be studied. Many other studies dealt with the development of achievement motivation, especially in an attribution-theoretical context (Heckhausen in press; Schmalt and Meyer 1976).

[3] In the fall of 1981 a conference on these topics was held at the Technical University of Berlin, organized by Görlitz and Wohlwill. 
(6) Values and morality. There is a relatively small but stable group of people interested in moral development from a Kohlbergian point of view (Oser 1981; Döbert and Nunner-Winkler 1975; Keller 1980; Eckensberger and Reinshagen 1980; and Eckensberger in press). In a series of publications, Eckensberger and his group at the University of Saarland attempted to reformulate the stage theory of Kohlberg (for instance, Eckensberger 1981). A reanalysis of the original Kohlberg data is planned.

We will conclude this section with a short look at the theoretical orientations of developmental research. Groffmann (1978) analyzed articles in 26 German journals with regard to their theoretical position (if any). In the period from 1969 to 1973, cognitive theories, learning theories, and stage theories (in this sequence) were at the head. In table 7, data on the diverse theoretical points of view are summarized.

As expected, cognitive theories rank first. About $40 \%$ of the studies reported in GJP and Child Development as well as of the current studies are more or less definitely related to cognitive theories. Among current studies, transactional as well as cognitive-structural theories receive some attention.

Table 7

Summary of percentage of studies by type of theoretical points of view. ${ }^{\text {a }}$

\begin{tabular}{|c|c|c|c|c|}
\hline & \multirow{2}{*}{$\begin{array}{l}\text { International } \\
\text { Psychological } \\
\text { Abstracts } 1975\end{array}$} & \multirow{2}{*}{$\begin{array}{l}\text { U.S. } \\
\text { Child } \\
\text { Development } \\
\text { 1978-81 }\end{array}$} & \multicolumn{2}{|c|}{ German-speaking } \\
\hline & & & $\begin{array}{l}\text { German } \\
\text { J. Psychology } \\
1977-81\end{array}$ & $\begin{array}{l}\text { Current } \\
\text { studies } \\
1981\end{array}$ \\
\hline $\begin{array}{l}\text { (1) Biological developmental } \\
\text { theories }\end{array}$ & 7 & 3 & 1 & 3 \\
\hline (2) Imprinting models & 12 & 1 & 1 & 0 \\
\hline (3) Transactional approaches & 7 & 11 & 3 & 11 \\
\hline (4) Learning theories & 13 & 6 & 5 & 4 \\
\hline (5) Cognitive theories & 19 & 37 & 44 & 44 \\
\hline $\begin{array}{l}\text { (6) Cognitive-structural } \\
\text { theories }\end{array}$ & 13 & 18 & 4 & 13 \\
\hline (7) Descriptive approaches & 4 & 13 & 28 & 6 \\
\hline (8) Other & 24 & 11 & 13 & 19 \\
\hline
\end{tabular}

a Total number of studies $=920$ (Psychological Abstracts), 594 (Child Development), 61 (German J. Psychology), and 148 (current studies). Entries of the first and third column sum to $99 \%$ and $98 \%$, respectively, because of rounding error. 
If one looks at the large group of cognitive theories, there apparently seems to be a trend towards relatively complex action-theoretic models. Two prototypes could be distinguished: (1) motivational approaches represented by theories of the expectancy-value type (see Heckhausen 1980); (2) performance-oriented approaches based on an elaboration of the Miller, Galanter and Pribram-type of models (see Volpert 1982 for an overview; Frese et al. 1978). Up to now, empirical research and a developmental perspective was concentrated on the first approach. Recently, however, some research efforts were stimulated by the latter model.

An action-theoretical-perspective provides a heuristic for analyzing individual as well as environmental factors in a common framework (Lantermann 1980a; Kaminski 1980). What is urgently needed, however, is more empirical research. Several projects on this topic have been started recently.

The analysis of the development of action-regulating systems probably provides a framework for many of the more prominent German research efforts. To quote only a few: coping strategies, socio-cognitive processes, achievement motivation, etc.

A very brief comment on the application of developmental psychology follows.

\subsection{Applied developmental psychology}

It is impossible to summarize the numerous applications of developmental research. A general trend, however, should be mentioned: there is an increasing interest in a genuine developmentally oriented applied psychology (Hetzer et al. 1979; Montada 1980). The tasks of an applied developmental psychology can be summarized as follows (Montada 1979): (1) prediction of the extent of stability and change, (2) analysis of objectives for developmental intervention, (3) construction of intervention programs.

In West Germany, there are many pressing societal problems to solve which require the work of developmentalists: humanization of working conditions, integration of foreign immigrants, youth protest, etc. Up to now, many of the Government-commissioned projects on these topics overlook our efforts.

Late in 1981, a meeting was held in Trier (Montada et al. 1981) which will hopefully instigate research as well as public relations with 
regard to more application of developmental research.

Applied developmental psychology is conceived as filling the gap between (basic) developmental research, on the one hand, and practical means of influencing development, on the other. As opposed to many researchers' beliefs, contemporary contributions to the logic of science stress the position that there is no direct, i.e. logical-systematical link beween basic research and application. Bunge (1967) as well as German proponents such as Brandtstädter (1980) developed a concise system of intermediate steps: substantive and operative technological theories, as well as technological rules, are conceptualized as heuristic foundations (via nomopragmatic statements in Bunge's terminology) of practical applications. In contrast to scientific theories in the strict sense, technological rules do not have truth values but effectiveness values. This is why successful practical application is not the touchstone of good theories.

If one looks at practical problems which demand intervention in developmental processes, one is surprised how unsystematically and almost blindly the steps of the theoretical foundation of programs are pursued. A prominent aim of applied developmental psychology would be not only to provide us with effectively working and theoretically sound technological rules, but also to gather experiences and initiate systematic research on the principles of funding (Bunge) intervention rules for development. The Trier conference could be a starting point for such new efforts in the Federal Republic.

\section{Communication}

As one of the activities which accompanied the Volkswagen program, the first Tagung Entwicklungspsychologie was held in 1976 (Heckhausen 1976). In September 1981, the fifth meeting took place in Augsburg (Oerter 1982). The series of meetings demonstrated the growing interest in developmental psychology. At the fourth meeting in Berlin which one of us was pleased to organize (Silbereisen 1980a), for instance, about 400 participants attended about a dozen study groups, as well as several lectures and symposia.

In the German-speaking countries, about 20 psychological journals are published. As recent analyses of citation frequencies (Nussbaum and Feger 1978; Marx 1980) show, about a dozen of these journals 
form a communication-network. The Zeitschrift für Entwicklungspsychologie und Pädagogische Psychologie (ZEP) - the only journal with a specialization on developmental psychology - belongs to an even smaller inner circle of high ranking journals with especially demanding methodological standards. The ZEP is regularly abstracted in the repeatedly mentioned German Journal of Psychology as well as in the Psychological Abstracts. Besides the ZEP, several other journals publish studies related to developmental psychology.

Nickel (1980), for instance, made up a list of 24 journals containing articles on child development.

As Irle (1977) pointed out for German psychology, a lot of research is only semipublished in gray market publications issued by research institutions or by individual authors themselves. This is also true for developmental psychology.

Coming to an end, we would like to comment on the asymmetry of the international communication between psychologists. According to Nussbaum and Feger (1978), in 1973 over $60 \%$ of the citations in German psychological journals were related to studies originally published in U.S. journals. Unfortunately, however, this reception of the North American literature in German-speaking countries is a one-way street. Graumann (1976) demonstrated this lack of mutual exchange in a comparison of citations between four journals of social psychology, that is two U.S. journals, one European journal published in English, and one German journal. The flow of citations is strikingly one-sided. Whereas $80 \%$ of the citations in the two European journals relate to the U.S. Journals, less than $2 \%$ of the latter's citations relate to articles published in Europe. Obviously, the English language in itself is not the decisive factor - one simply has to publish in a North American journal.

We stress this point in a paper on trends of developmental psychology due to the fact that German developmentalists are becoming more and more sensitized with respect to the problem of international communication. For the period from 1967 to 1978 Becker (1980) showed a steady increase in English publications of German authors in periodicals. In absolute figures, however, this increase has to be qualified: only eight authors published regularly in English (that is, at least four times). The bulk of researchers who published at least once in English was concentrated at four of 33 departments, namely Bochum, Düsseldorf, Mannheim, and Marburg. 
With regard to trends in developmental psychology, the content of the publications is disappointing. Only 11 out of a total of 217 articles could be classified as developmental. Several other topics outnumber developmental psychology in frequency (ranked from top): experimental social psychology, perception and motor performance, cognitive processes and motivation, psychometrics, personality, and physiological psychology. Obviously, developmental psychology in German-speaking countries - at least the current research literature - is not received by the international scientific community. The basic research on cognitive processes and motivation of Heckhausen's group in Bochum, often relevant for developmental psychology, may be an exception. This, however, provides a somewhat incomplete view of the priorities of developmental psychology in West Germany.

As already mentioned, the number of English language publications by German authors is growing. Two international journals seem to be especially important for German developmentalists: Human Development (in earlier years edited by Thomae; former title Vita Humana) and International Journal of Behavioral Development. In both journals German researchers regularly contribute as consulting editors and authors. Vita Humana, for instance, placed an eminent role in multiplicating the early German life-span conceptions.

The initiation of cross-national research projects will probably provide greater opportunities of balancing the flow of information.

\section{References}

Adressenverzeichnis Entwicklungspsychologen. Schuhler, P. and R.K. Silbereisen (ed.), 1981. West Berlin: Technische Universität Berlin.

Baltes, M.M. and P.B. Baltes, 1982. 'Micro-analytical research on environmental factors and plasticity in psychological aging'. In: I. Field et al. (eds.), Review of human development. New York: Wiley.

Baltes, P.B., J. Brandtstädter, H. Rauh and R.K. Silbereise, 1981. Postgraduale Ausbildung in Entwicklungspsychologie: ein institutionsübergreifender Modellversuch. Unpublished paper.

Becker, J.H., 1980. Englischsprachige Publikation deutscher Psychologen. Trends, Inhalte, Herkunft, internationale Aufnahme. Psychologische Beiträge 22, 356-371.

Becker, H., 1981. Antrag an die Deutsche Forschungsgemeinschaft auf Gewährung einer Sachbeihilfe 'Zur Bedeutung des Handlungsrahmens von Jugendlichen als Teil ihrer Lebenswelt'. Unpublished paper.

Beller, K.E., 1979. Die Gruppenzusammensetzung in Krippen und ihre Wirkung auf Entwicklungsveränderungen im sozialen Verhalten bei Zweijährigen. Paper presented at the 4. Tagung Entwicklungspsychologie. Berlin (West).

Brandtstädter, J., 1980. 'Relationships between life-span developmental theory, research, and 
intervention: a revision of some stereotypes'. In: R.R. Turmer and H.D. Reese (eds.), Life-span developmental psychology: intervention. New York: Academic Press.

Bronfenbrenner, U., 1977. Toward an experimental ecology of human development. American Psychologist 32, 513-531.

Bunge, M., 1967. Scientific research: the search for truth. Berlin: Springer.

Burger, Ch., T. Füchsle and G. Trommsdorff, 1981. Zeitperspektive in ihrer Bedeutung für Entscheiden und Handeln. Progress report Sonderforschungsbereich 24. University of Mannheim.

Chapman, M., in press. Action and interaction: the study of social cognition in Germany and the United States of America. Human Development.

Coerper, C., W. Hagen and H. Thomae (ed.), 1954. Deutsche Nachkriegskinder. Methoden und erste Ergebnisse der deutschen Längsschnittuntersuchungen an Kindern und Jugendlichen. Stuttgart: Thieme.

Cranach, M. v., U. Kalbermatten, K. Indermühle and B. Gugler, 1980. Zielgerichtetes Handeln. Bern: Huber.

Dann, H.-D., B. Cloetta, G. Müller-Fohrbrodt and R. Helmreich, 1978. Umweltbedingungen innovativer Kompetenz. Eine Längsschnittstudie zur Socialization von Lehrern in Ausbildung und Beruf. Stuttgart: Klett-Cotta.

Deutsche Forschungsgemeinschaft, 1977. Forschungsbericht Schwangerschaftsverlauf und Kindesentwicklung. Boppard: Boldt.

Deutsche Forschungsgemeinschaft, 1979. Tätigkeitsbericht, Band 1. Bonn: Deutsche Forschungsgemeinschaft.

Döbert, R. and G. Nunner-Winkler, 1975. Adoleszenzkrise und Identitätsbildung. Frankfurt am Main: Suhrkamp.

Eckensberger, L.H., 1981. 'A structural model of the development of stages of moral development'. In: L. Oppenheimer (ed.), Action theoretical approaches to (developmental) psychology. Proceedings of the Symposium: Action Theory and Developmental Psychology. Report 1981-04. Amsterdam: Universiteit von Amsterdam. pp. 17-54.

Eckensberger, L.H., 1981. Zur Entwicklung von Konfliktlösungsvorstellungen. Study supported by a grant from the Stiftung Volkswagenwerk.

Eckensberger, L.H., in press. Research on moral development in Germany. German Journal of Psychology.

Eckensberger, L.H. and H. Reinshagen, 1980. 'Kohlbergs Stufentheorie der Entwicklung des Moralischen Urteils: ein Versuch ihrer Reinterpretation im Bezugsrahmen handlungstheoretischer Konzepte'. In: L.H. Eckensberger and R.K. Silbereisen (eds.), Entwicklung sozialer Kognitionen. Stuttgart: Klett-Cotta. pp. 65-132.

Eckensberger, L.H. and R.K. Silbereisen, 1980. Entwicklung sozialer Kognitionen. Stuttgart: Klett-Cotta.

Edelstein, W., M. Keller and K. Wahlen, 1976. Kindliche Entwicklung und soziale Struktur. Supported by funds from the Max-Planck-Institute for Human Development and Education. Berlin (West).

Eyferth, K., 1980. 'Bericht über eine Umfrage über die Ausbildung im zweiten Studienabschnitt des Diplomstudiengangs Psychologie'. In: E. Stephan (ed.), Ausbildung und Weiterbildung in Psychologie. Weinheim: Beltz. pp. 8-21.

Filipp, S.-H., 1980. Entwicklung von Selbstkonzepten. Zeitschrift für Entwicklungspsychologie und Pädagogische Psychologie 12, 105-125.

Filipp, S.-H., A. Angleitner, I. Ahammer and E. Olbrich, 1980. Antrag auf Weiterführung des Projekts 'Entwicklungspsychologie des Erwachsenenalters' an die VW-Stiftung. Universität. Trier: Forschungsbericht Nr. 11.

Fisch, R. and H.D. Daniel, 1981. Die Lage der Forschung im Fach Psychologie im Urteil der Kollegen. Psychologische Rundschau 2, 103-117. 
Fischer, H., 1979. 'Entwicklung der Wahrnehmung'. In: L.H. Eckensberger (ed.), Bericht über den 31. Kongress der Deutschen Gesellschaft für Psychologie. Göttingen: Hogrefe. pp. 219-222.

Foppa, K. and R. Groner (ed.), 1981. Kognitive Strukturen und ihre Entwicklung. Bern: Huber.

Frese, M., S. Greif and N. Semmer, 1978. Industrielle Psychopathologie. Bern: Huber.

Frielingsdorf, Ch. and H. Rauh, 1977. Entwicklungspsychologie in der Bundesrepublik: Ausbildung, Ausstattung und Forschungsaktivität. Zeitschrift für Entwicklungspsychologie und Pädagogische Psychologie 9, 97-109.

Gerber, A. and H. Fischer, 1981. 'Das Erkennen von eingebetteten Figuren bei kurzfristiger Darbietung in seiner Entwicklung bis ins höhere Alter'. In: W. Michaelis (ed.), Bericht über den 32. Kongres der Deutschen Gesellschaft für Psychologie in Zürich, Band 1. Göttingen: Hogrefe. pp. 203-206.

Graumann, C.F., 1976. Transmissions and refractions: vicissitudes in the European-American exchange of ideas. Lecture to the APA-Convention, Washington.

Groffmann, K.J., 1978. Zur Frage der Orientierung der entwicklungspsychologischen Forschung an Entwicklungstheorien. Archiv für Psychologie 130, 97-106.

Grossmann, K., 1980. 'Bericht über die Arbeitsgruppe 'Sozial-emotionale Entwicklung in der frühen Kindheit'. In: R.K. Silbereisen (ed.), Bericht über die 4. Tagung Entwicklungspsychologie. West Berlin: Technische Universität Berlin, Dokumentation Kongresse und Tagungen. pp. 385-400.

Hanke, B., J.B. Lohmöller and H. Mandl, 1980. Schülerbeurteilung in der Grundschule. München: Oldenburg.

Heckhausen, H., 1976. Tagung 'Entwicklungspsychologie' in Bochum. Zeitschrift für Entwicklungspsychologie und Pädagogische Psychologie 8, 228-234.

Heckhausen, H., 1980. Motivation und Handeln. Berlin (West): Springer.

Heckhausen, H., in press. 'The development of achievement motivation'. In: W.W. Hartup (ed.), Review of child development research, vol. 6. Chicago: University of Chicago Press.

Hetzer, H., E. Todt, I. Seiffge-Krenke and R. Arbinger, 1979. Angewandte Entwicklungspsychologie des Kindes- und Jugendalters. Heidelberg: Quelle und Meyer.

Hoff, E.H., 1981. Sozialisation als Entwicklung der Beziehungen zwischen Person und Umwelt. Zeitschrift für Sozialisationsforschung und Erziehungssoziologie 1, 91-115.

Hogrefe, C.J., 1981. Psychologenkalender. Göttingen: Verlag für Psychologie.

Hohner, H.U. and H.-D. Dann, 1979. Unmittelbare und langfristige Umwelteffekte auf die Entwicklung konservativer Einstellungen. Zeitschrift für Entwicklungspsychologie und Pädagogische Psychologie 11, 322-334.

Hussy, W., 1979. Informationsverarbeitende Strukturen und Prozesse: Versuch einer allgemeinund entwicklungspsychologischen Modellbildung. Trierer Psychologische Berichte 6.

Irle, M., 1977. The state of psychology in the Federal Republic of Germany. German Journal of Psychology 1, 3-12.

Irle, M., 1979. Zur Lage der Psychologie. Psychologische Rundschau 30, 1-18.

Kaminski, G., 1980. 'Acht Thesen zum Verhältnis von Ökopsychologie und Entwicklungspsychologie'. In: R.K. Silbereisen. Bericht über die 4. Tagung Entwicklungspsychologie. West Berlin: Technische Universität Berlin, Dokumentation, Kongresse und Tagungen. pp. 106-110.

Keller, H., 1979. Geschlechtsunterschiede in der Reaktion auf auditive Reize in den ersten drei Lebensmonaten. Zeitschrift für Entwicklungspsychologie und Pädagogische Psychologie 11, $185-194$.

Keller, H. and E. Werner-Bonus, 1978. Vater-Kind-Interaktionen bei drei Monate alten Säuglingen. Zeitschrift für Entwicklungspsychologie und Pädagogische Psychologie 10, 279-285.

Keller, M., 1978. Bericht über die Tagung Entwicklungspsychologie in Marburg. Zeitschrift für Entwicklungspsychologie und Pädagogische Psychologie 10, 274-276.

Keller, M., 1980. 'Soziale Kognition, Moralisches Urteil und Ich-Prozesse'. In: L.H. Eckensberger and R.K. Silbereisen (eds.), Entwicklung sozialer Kognitionen. Stuttgart: Klett-Cotta. pp. 163-184. 
Kluwe, R.H., 1981. 'Cognitive knowledge and executive control: metacognition'. In: D. Griffin (ed.), Animal mind - human mind. Berlin (West): Springer.

Kluwe, R.H. and H. Spada (eds.), 1980. Developmental models of thinking. New York: Academic Press.

Kossakowski, A., 1980. Psychology in the German Democratic Republic. American Psychologist $35,450-460$.

Kreppner. K., 1978. Überlegungen zur Entwicklung eines theoretischen Rahmens zur Analyse frühkindlicher Sozialisationsprozesse. Neue Sammlung 18, 30-54.

Kreppner, K., S. Paulsen and Y. Schütze, 1978. Frühkindliche Sozialisation. Supported by funds from the Max-Planck-Institute for Human Development and Education, Berlin.

Krohne, H.W., 1980. 'Parental child-rearing behavior and the development of anxiety and coping strategies in children'. In: C.D. Spielberger and I.G. Sarason (eds.), Stress and anxiety. Washington, DC: Hemisphere. pp. 233-246.

Lantermann, E.-D., 1980a. Interaktionen - Person, Situation und Handlung. München: Urban \& Schwarzenberg.

Lantermann, E.D., 1980b. Urteile über Einstellungsobjekte im Handlungskontext. Unpublished paper.

Lehr, U. 1969. Die Frau im Beruf - eine entwicklungspsychologische Analyse der weiblichen Berufsrolle. Frankfurt: Athenäum.

Lukesch, H., M. Perrez and K. Schneewind, 1980. Familiäre Sozialisation und Intervention. Bern: Huber.

Marx, W., 1980. Die Interaktions-Struktur des deutschsprachigen psychologischen Zeitschriftensystems. Psychologische Rundschau 31, 174-186.

Mandl, H. and G. Huber, in press. Emotion und Kognition. München: Urban \& Schwarzenberg.

McCandless, B.R. and M.F. Geis, 1975. 'Current trends in developmental psychology'. In: H.W. Reese (ed.), Advances in child development and behavior, vol. 9. New York: Academic Press. pp. 1-8.

Merz, F. and T. Ehlers, 1980. 'Längsschnittuntersuchungen in der Bundesrepublik Deutschland: Erfahrungsaustausch'. In: R.K. Silbereisen (ed.), Bericht über die 4. Tagung Entwicklungspsychologie. West Berlin: Technische Universität Berlin, Dokumentation Kongresse und Tagungen. pp. 203-220.

Montada, L., 1979. Brennpunkte der Entwicklungspsychologie. Stuttgart: Kohlhammer.

Montada, L., 1980. 'Überlegungen zu einer Angewandten Entwicklungspsychologie'. In: R.K. Silbereisen (ed.), Bericht über die 4. Tagung Entwicklungspsychologie. West Berlin: Technische Universität Berlin, Dokumentation Kongresse und Tagungen. pp. 9-38.

Montada, L., H. Rauh and R.K. Silbereisen, 1981. Symposium 'Probleme der Angewandten Entwicklungspsychologie', Trier. Unpublished paper.

Mummendey, H.D. and G. Sturm, 1981. Zweiter Bericht über eine Längsschnittuntersuchung zu kritischen Lebensereignissen und Selbstbildänderungen jüngerer Erwachsener. Bielefelder Arbeiten zur Sozialpsychologie 72.

Nickel, H., 1980. Child psychology. A review of 30 years of research in the Federal Republic of Germany. German Journal of Psychology 4, 313-334.

Nickel, H. and U. Schmidt-Denter, 1980. Sozialverhalten von Vorschulkindern. München: Reinhardt.

Nussbaum, A. and H. Feger, 1978. Analyse des deutschsprachigen psychologischen Zeitschriftensystems. Psychologische Rundschau 24, 91-112.

Oerter, R., 1979. 'Entwicklung im Jugendalter - ein umweltorientierter Ansatz'. In: H. Rauh (ed.), Jahrbuch für Entwicklungspsychologie. Stuttgart: Klett-Cotta. pp. 83-156.

Oerter, R., 1982. Bericht über die Tagung Entwicklungspsychologie 1981 in Augsburg. Zeitschrift für Entwicklungspsychologie und Pädagogische Psychologie 14, 81-89.

Oerter, R., E. Dreher and M. Dreher, 1977. Kognitive Sozialisation und subjektive Struktur. München: Oldenbourg. 
Olbrich, E., I. Seiffge-Krenke and F.J. Mönks, 1980. Antrag an die Deutsche Forschungsgemeinschaft auf Gewährung einer Sachbeihilfe 'Coping im Jugendalter'. Unpublished paper.

Oser, F., 1981. Moralisches Urteil in Gruppen, Soziales Handeln und Verteilungsgerechtigkeit: Stufen der interaktiven Entwicklung und ihre erzieherische Stimulation. Frankfurt am Main: Suhrkamp.

Papousek, H. and M. Papousek, 1978. Interdisciplinary parallels in studies of early human behavior: from physical to cognitive needs, from attachment to dyadic interaction. International Journal of Behavioral Development 1, 37-49.

Rauh, H., 1981. Bericht über die Tätigkeit des Koordinierungskreises Entwicklungspsychologie im Rahmen des Schwerpunktförderungsprogramms Entwicklungspsychologie der Stiftung Volkswagenwerk. Unpublished paper.

Rauh, H., Ch. Schmid-Schönbein and T. Thiel, 1979. Der Aufbau kognitiver Strukturen als Äquilibrationsprozess. Supported by a grant from the Stiftung Volkswagenwerk.

Ritter, M. and T. Rotarius, 1978. Eine Untersuchung zum Training der visuellen Differenzierung bei Grundschulkindern. Zeitschrift für Entwicklungspsychologie und Pädagogische Psychologie $10,144-156$.

Roth, E., 1981. Zur Lage der Psychologie. Psychologische Rundschau 32, 1-15.

Rudinger, G., 1981. Tendenzen und Entwicklungen entwicklungspsychologischer Versuchsplanung - Sequenzanalysen. Psychologische Rundschau, 118-136.

Scherer, K.R., 1981. 'Wider die Vernachlässigung der Emotion in der Psychologie'. In: W. Michaelis (ed.), Bericht über den 32. Kongress der Deutschen Gesellschaft für Psychologie in Zürich 1980, Band 1. Göttingen: Hogrefe. pp. 304-317.

Schmalt, H.D. and W.U. Meyer (eds.), 1976. Leistungsmotivation und Verhalten. Stuttgart: Klett-Cotta.

Schmidt, H.D., 1980. Psychology in the German Democratic Republic. Annual Review of Psychology 31, 195-209.

Schmitz, P.G., 1979. Trends in der entwicklungspsychologischen Forschung: Analyse der Psychological Abstracts 1963-1976 unter besonderer Berücksichtigung der Jahrgänge 1965, 1970 und 1975. Zeitschrift für Entwicklungspsychologie und Pädagogische Psychologie 11, 16-30.

Schmitz-Scherzer, R., 1977. Zur Veränderung des Freizeit- und Sozialverhaltens. Zeitschrift für Gerontologie 10, 300-321.

Siegert, M.T., 1981. The interaction of ontogenetic, family, and social change processes in the development of juvenile drug addiction. Paper presented at the Sixth Biennal Meetings of the International Society for the Study of Behavioural Development, 17-21 Aug. Toronto.

Silbereisen, R.K., 1980a. Tagung Entwicklungspsychologie ' 79 in Berlin (West). West Berlin: Technische Universität Berlin, Dokumentation Kongresse und Tagungen.

Silbereisen, R.K., 1980b. Bericht über die 4. Tagung Entwicklungspsychologie. Zeitschrift für Entwicklungspsychologie und Pädagogische Psychologie 12, 96-102.

Silbereisen, R.K. and K. Eyferth, 1981. Jugendentwicklung und Drogen: eine prospektive Längsschnittstudie bei 12 - bis 17 jährigen. Supported by a grant from the Deutsche Forschungsgemeinschaft.

Silbereisen, R.K., K. Eyferth and G. Rudinger, 1981. Antrag an die Deutsche Forschungsgemeinschaft auf Unterstützung einer internationalen Fachkonferenz 'Entwicklungspsychologische und ökologische Forschung zur Jugendentwicklung: Integration von zwei Ansätzen'. Unpublished paper.

Spada, H., 1978. Understanding proportionality: a comparison of different models of cognitive development. International Journal of Behavioral Development 1, 363-376.

Thomae, H. (ed.), 1976. Patterns of aging. Basel: Karger.

Thomae, H., 1978. Psychogerontology in Germany. German Journal of Psychology 2, 54-68. 
Thomae, H., 1979. '50 Jahre Längsschnittforschung. Ein Beitrag zur Trendanalyse der Entwicklungspsychologie'. In: L. Montada (ed.), Brennpunkte der Entwicklungspsychologie. Stuttgart: Kohlhammer. pp. 31-41.

Thomae, H. and U. Lehr, 1965. Konflikt, seelische Belastung und Lebensalter. Köln: Westdeutsche Verlagsanstalt.

Trautner, H.M., 1981. Entwicklung und Zusammenhangsmuster von Merkmalen der Geschlechtstypisierung im Kindesalter. Supported by a grant from the Stiftung Volkswagenwerk.

Vetter, M., 1980. Ich-Entwicklung und kognitive Komplexität. Zeitschrift für Entwicklungspsychologie und Pädagogische Psychologie 12, 126-143.

Volpert, W., 1982. 'The model of hierarchical-sequential organization of action'. In: W. Hacker, W. Volpert and M. von Cranach (eds.), Cognitive and motivational aspects of action. Berlin (GDR): Deutscher Verlag der Wissenschaften.

Voss, H.G., 1979. Entwicklung explorativen Verhaltens in der frühen Kindheit (2.-4. Lebensjahr) und Genese des Neugiermotivs. Supported by a grant from the Stiftung Volkswagenwerk.

Voss, H.G. and H. Keller, 1981. Neugierforschung. Weinheim: Beltz.

Waller, M., 1974. Stand und Trends entwicklungspsychologischer Forschung - Möglichkeiten ihrer Förderung. Abschlussbericht über das Symposium in Salzburg. Unpublished paper.

Waller, M., 1977. Tagung 'Entwicklungspsychologie' in Konstanz. Zeitschrift für Entwicklungspsychologie 9, 294-297.

Weinert, F., 1980. Bericht über den Schwerpunkt 'Entwicklungspsychologie' für das Kuratorium der Volkswagen-Stiftung. Unpublished paper.

Weinert, F., B. Treiber and W. Schneider, 1979. Educational Psychology. German Journal of Psychology 3, 236-266.

Wilkening, F., 1979. Combining of stimulus dimensions in children's and adults' judgements of area: an information integration analysis. Developmental Psychology 15, 25-33.

Wilkening, F., 1981. Integrating velocity, time, and distance information: a developmental study. Cognitive Psychology 13, 231-247.

Wilkening, F., J. Becker and T. Trabasso (eds.), 1980. Information integration by children. Hillsdale: Erlbaum.

Wimmer, H., 1976. Aspekte der Gedächtnisentwicklung. Zeitschrift für Entwicklungspsychologie und Pädagogische Psychologie 8, 62-78. 